\title{
Can Co-enzyme Q10 improve the chances of conception after the age of 35 ?
}

\author{
Eman Ali Abd El Fattah*
}

Department of Obstetrics and Gynecology, Alexandria University, Shatby Maternaty Hospital, Alexandria, Egypt

Received: 15 May 2017

Accepted: 10 June 2017

\section{*Correspondence:}

Dr. Eman Ali Abd El Fattah,

E-mail: eman0eman0eman7@gmail.com

Copyright: () the author(s), publisher and licensee Medip Academy. This is an open-access article distributed under the terms of the Creative Commons Attribution Non-Commercial License, which permits unrestricted non-commercial use, distribution, and reproduction in any medium, provided the original work is properly cited.

\begin{abstract}
Background: ovarian follicular quality diminishes with age, Free radicals and oxidative stress begin to accumulate in cells, aging or slowing down the metabolic energy production centers in the cell- the mitochondria. When the mitochondria cannot generate a certain amount of energy, it slows growth and proper development of the follicle making it more prone to DNA damage, including chromosomal abnormalities resulting in poor fertilization patterns, and early miscarriage. Co-enzyme Q10 (CoQ10) is a major cellular antioxidant. its tissue levels gradually decrease with age. We attempt to evaluate its protective effect on ROS-induced ovarian damage, which is one of the most important and widely accepted patho- mechanisms underlying cell ageing.

Methods: 40 Participants from El Shatby hospital infertility clinic 35 to 38 years old, with history of bad response to ovulation stimulation, were divided into two equal groups (group A given (CoQ10) 3mg|kg body weight for three cycles prior to stimulation Serum anti- mullarian hormone level was measured before and after CoQ10 administration, group $\mathrm{B}=$ twenty cases as control). Participants were given gonadotrophins (150 IU to $375 \mathrm{IU}$ ). Follicular growth was monitored by trans- vaginal ultra- sonography and serum estradiol level (E2). Ovulation trigger was achieved using 10,000 IU of human chorionic gonadotrophin.
\end{abstract}

Results: The primary outcome was occurrence of normal pregnancy; secondary outcome was good response to stimulation (at least one mature follicle $18-22 \mathrm{~mm}$ ).

Conclusions: CoQ10 has no significant effect on response to ovulation stimulation or on pregnancy rates.

Keywords: Co- enzyme Q10, Ovarian reserve, Pregnancy

\section{INTRODUCTION}

Increased female age results in a decline in reproductive outcome and an associated increase in chromosomal aberrations.

Molecular pathways behind increased loss of germ cells in aged ovaries are poorly understood. Increased DNA damage due to less active DNA repair machinery is one possible trigger for oocyte loss. ${ }^{1}$ The complex process of oocyte maturation prior to ovulation involves nuclear, cytoplasmic, and epigenetic changes culminating with the formation of the meiotic spindle. All of these processes require energy, which is provided by mitochondria. ${ }^{2}$

Therefore, the number of mitochondria markedly increases to provide adequate energy production to meet the metabolic requirements during the transition of a primordial follicle into a primary follicle. All energydependent mechanisms of human fertility are influenced by mitochondrial damage which is based on oxidative stress (Free radical theory, is the second most commonly 
accepted theory and is strongly associated with ovarian ageing after physiological programmed ageing, which is the most commonly accepted theory. ${ }^{3}$ Because mitochondrial damage results in an increased accumulation of reactive oxygen species (ROS) and mitochondrial DNA mutations, the increased release of intracellular ROS due to MD, which cannot be counteracted by antioxidant defences similar to those of ageing cells, induces damage to ovarian tissue. ${ }^{4}$ The exposure to high levels of ROS may eventually contribute to granulosa cell apoptosis, follicular atresia, chromosomal abnormalities, oocyte ageing, and infertility. ${ }^{5}$ Older cells tend to produce more oxidants and less ATP than younger cells from their mitochondria because of a positive correlation between the level of ROS production and chronological age. The potentially adverse effects of OS in most stages of human fertility can be counteracted by administration of several mitochondrial nutrients known as antioxidants, which have been demonstrated to increase energy production in mitochondria and to protect cells from OS. Alpha-lipoic acid (RALA), vitamin C, CoQ10, and resveratrol are the best and most commonly used antioxidants in current studies. $^{6}$

Co-enzyme Q10 (CoQ10), a fat-soluble component of nearly all cell membranes, is located in the inner mitochondrial membrane. CoQ10 is an essential component for transporting electrons in the mitochondrial respiratory chain to produce cellular energy. Moreover, the reduced form of CoQ10, known as ubiquinol, acts as an antioxidant in cellular metabolism via inhibition of lipid peroxidation, protein, and DNA oxidation. ${ }^{7,8}$

Although CoQ10 is synthesised by virtually all normal tissues, the tissue levels of CoQ10 gradually decrease with ageing. ${ }^{9}$

The study attempted to evaluate the protective effect of CoQ10 on ROS-induced ovarian damage, which is one of the most important and widely accepted pathomechanisms underlying cell ageing. This could also lead to biochemical alternatives for the management of women with poor ovarian reserve during IVF treatment.

\section{METHODS}

Patient enrollment into the study began in 1 August 2014 and was continued until 1 August 2016.

Participants were selected from El Shatby hospital infertility clinic their age ranged from 35 to 38 years, with history of bad response to ovulation stimulation. Participants fulfilling these criteria were forty in number, they were divided into two groups each of twenty cases (group $\mathrm{A}=$ they were given co-enzyme Q10 (CO- Q10) in a dose of $3 \mathrm{mg} / \mathrm{kg}$ body weight for three cycles prior to stimulation. Serum anti- mullarian hormone level was measured before and after COQ 10 administration, group $\mathrm{B}=$ twenty cases taken as control).

\section{Serum AMH concentrations}

Serum AMH levels were measured by USCN Life Science enzyme-linked immunosorbent assays (ELISA). The assay range was $0.31-20 \mathrm{ng} / \mathrm{mL}$, and the minimum detectable dose of this assay was less than $0.078 \mathrm{ng} / \mathrm{mL}$. The technician was unaware of the treatment allocation.

Participants were given gonadotrophins in doses ranging from $150 \mathrm{IU}$ to $375 \mathrm{IU} /$ day (Purified FSH vials 75-150 IU Gonapure- Menapharm- Egypt, and LH vials 75- 150 IU Merional- IBSA- Switzerland) started on day 2 of the fourth cycle. Monitoring of follicular growth was done by trans- vaginal ultra- sonograhpy (Medison R-7, vaginal transducer 8-MZ). The dose of gonadotrophins was monitored according to the response. Follicular maturation was followed up untill at least one mature follicle of 18-20 mm diameter was obtained. Serum estradiol level (E2) was measured, CO Q10 was discontinued and ovulation trigger was achieved using 10,000 IU of human chorionic gonadotrophin HCG (choriomon 5000 IU, intra- muscular injection, IBSASwitzerland). Vaginal progesterone (cyclogest 400mg) was used twice daily for luteal phase support for fourteen days then pregnancy test in serum was done. Positive cases were followed up till an intra- uterine gestational sac with positive cardiac pulsations was seen by transvaginal ultra- sonograhpy. During the trial, five cases from group B and one case from group A did not continue the follow up so they were excluded from the study.

The primary outcome was occurrence of normal pregnancy (intra- uterine gestational sac with positive cardiac pulsations on trans- vaginal ultra- sonograhpy), the secondary outcome was good responce to stimulation namely the presence of at least one mature follicle of diameter $18-22 \mathrm{~mm}$.

\section{Statistical methodology}

Data were collected and entered to the computer using SPSS (Statistical Package for Social Science) program for statistical analysis (version 21). ${ }^{10}$ Data were entered as numerical or categorical, as appropriate.

When Kolmogorov-Smirnov test revealed no significance in the distribution of variables, parametric statistics was carried out, while in the not-normally distributed data the non-parametric statistics was carried out. ${ }^{11}$

Data were described using minimum, maximum, mean, standard deviation and $95 \%$ CI of the mean for the normally distributed data.

Data were described using minimum, maximum, median and inter-quartile range for not-normally distributed data.

Categorical variables were described using frequency and percentage of total. 
Comparisons were carried out between two studied independent normally distributed subgroups using independent sample $\mathrm{t}$ test. When Levene's test for equality of variances is significant, Welch's t-test is used, which is an adaptation of Student's t-test, and is more reliable when the two samples have unequal variances and unequal sample sizes. ${ }^{12,13}$

Comparisons were carried out between two studied independent not-normally distributed subgroups using Mann-Whitney U test. ${ }^{14}$

Comparison between paired-variables in the same group was carried out using Wilcoxon Signed Ranks test.

Histograms with distribution curve, Box and Whiskers graph, bar chart and clustered bar chart were used accordingly. Chi-square test was used to test association between qualitative variables. Fisher's Exact test and Monte Carlo correction was carried out when indicated (expected cells less than 5).

An alpha level was set to $5 \%$ with a significance level of $95 \%$, and a beta error accepted up to $20 \%$ with a power of study of $80 \%$.

\section{RESULTS}

The two studied groups did not show any statistically significant difference as regards age (Table $1 ; \mathrm{p}=0.286$ ) neither did they as regards AMH levels (Table 2; $\mathrm{p}=0.349$ according to Levene's Test, and $\mathrm{p}=0.123$ according to independent samples t- test) AMH levels ranged from 0.8 to $1.9 \mathrm{ng} / \mathrm{ml}$ in the two groups.

No change was noticed in AMH level measured pre-and post COQ10 administration, where $\mathrm{p}=0.160$ which is statistically not significant (Table 2).

Table 1: Age (years).

\begin{tabular}{|c|c|c|c|}
\hline & $\begin{array}{l}\text { Placebo } \\
\text { group } \\
(n=15)\end{array}$ & $\begin{array}{l}\text { CoQ10 } \\
\text { group } \\
(n=19)\end{array}$ & $\begin{array}{l}\text { All cases } \\
(n=34)\end{array}$ \\
\hline Minimum & 35 & 35 & 35 \\
\hline Maximum & 40 & 40 & 40 \\
\hline Mean & 37.00 & 36.42 & 36.68 \\
\hline $\begin{array}{l}\text { Std. } \\
\text { deviation }\end{array}$ & 1.603 & 1.426 & 1.512 \\
\hline Median & 37.00 & 36.00 & 36.00 \\
\hline $\begin{array}{l}\text { Inter- } \\
\text { quartile } \\
\text { range }\end{array}$ & $\begin{array}{l}36.00- \\
38.00\end{array}$ & $\begin{array}{l}35.00- \\
38.00\end{array}$ & $\begin{array}{l}35.00- \\
38.00\end{array}$ \\
\hline $\begin{array}{l}\text { KS test of } \\
\text { normality }\end{array}$ & $\begin{array}{l}\mathrm{D}=0.200 \\
\mathrm{p}=0.108 \mathrm{NS}\end{array}$ & $\begin{array}{l}\mathrm{D}=0.248 \\
\mathrm{p}=0.003^{*}\end{array}$ & $\begin{array}{l}D=0.232 \\
p=0.000 *\end{array}$ \\
\hline $\begin{array}{l}\text { Mann- } \\
\text { Whitney U } \\
\text { Test }\end{array}$ & $\begin{array}{l}\mathrm{Z}=1.105 \\
\mathrm{p}=0.286 \mathrm{NS}\end{array}$ & & \\
\hline
\end{tabular}

$\mathrm{KS}=$ Kolmogorov-Smirnov; $*=\quad$ statistically significant $(\mathrm{p}<0.05)$; NS: statistically not significant $(\mathrm{p}>0.05)$
Table 2: AMH (ng/ml).

\begin{tabular}{|c|c|c|c|}
\hline & $\begin{array}{l}\text { Placebo } \\
\text { group } \\
(\mathbf{n}=15)\end{array}$ & $\begin{array}{l}\text { Co Q10 } \\
\text { group } \\
(n=19)\end{array}$ & $\begin{array}{l}\text { All cases } \\
(n=34)\end{array}$ \\
\hline \multicolumn{4}{|c|}{ Basal line AMH level } \\
\hline Minimum & 0.80 & 0.90 & 0.80 \\
\hline Maximum & 1.60 & 1.90 & 1.90 \\
\hline Mean & 1.24 & 1.38 & 1.32 \\
\hline Std. deviation & 0.219 & 0.293 & 0.269 \\
\hline Median & 1.20 & 1.40 & 1.30 \\
\hline $\begin{array}{l}\text { Inter-quartile } \\
\text { range }\end{array}$ & $\begin{array}{l}1.10- \\
1.40\end{array}$ & $\begin{array}{l}1.20- \\
1.60\end{array}$ & $\begin{array}{l}1.20- \\
1.45\end{array}$ \\
\hline $\begin{array}{l}\text { KS test of } \\
\text { normality }\end{array}$ & $\begin{array}{l}D=0.161 \\
p=0.200 \\
\text { NS }\end{array}$ & $\begin{array}{l}D=0.163 \\
p=0.200 \\
N S\end{array}$ & $\begin{array}{l}D=0.149 \\
p=0.054 \\
N S\end{array}$ \\
\hline $\begin{array}{l}\text { Levene's test for } \\
\text { equality of } \\
\text { variances }\end{array}$ & \multicolumn{3}{|c|}{$\begin{array}{l}F=0.903 \\
p=0.349 \mathrm{NS}\end{array}$} \\
\hline $\begin{array}{l}\text { Independent } \\
\text { samples t test }\end{array}$ & \multicolumn{3}{|c|}{$\begin{array}{l}\mathrm{t}_{(\mathrm{df}=32)}=1.585 \\
\mathrm{p}=0.123 \mathrm{NS}\end{array}$} \\
\hline \multicolumn{4}{|c|}{ Post CO Q10 AMH level } \\
\hline Minimum & \multicolumn{2}{|c|}{0.90} & \\
\hline Maximum & \multicolumn{2}{|c|}{1.90} & \\
\hline Mean & \multicolumn{2}{|c|}{1.4105} & \\
\hline Std. Deviation & \multicolumn{2}{|c|}{0.28847} & \\
\hline Median & \multicolumn{2}{|c|}{1.4000} & \\
\hline $\begin{array}{l}\text { Inter-quartile } \\
\text { range }\end{array}$ & \multicolumn{2}{|c|}{$1.30-1.60$} & \\
\hline $\begin{array}{l}\text { KS test of } \\
\text { normality }\end{array}$ & \multicolumn{2}{|c|}{$\begin{array}{l}D=0.199 \\
p=0.047 *\end{array}$} & \\
\hline $\begin{array}{l}\text { Wilcoxon signed } \\
\text { Ranks Test }\end{array}$ & \multicolumn{2}{|c|}{$\begin{array}{l}\mathrm{Z}=1.406 \\
\mathrm{p}=0.160 \mathrm{NS}\end{array}$} & \\
\hline
\end{tabular}

$\mathrm{KS}=$ Kolmogorov-Smirnov; $*=$ statistically significant $(\mathrm{p}<0.05)$; NS: statistically not significant $(p>0.05)$

Table 3: Doses of gonadotrophins (IU).

\begin{tabular}{|llll|}
\hline Minimum & $\begin{array}{l}\text { Placebo } \\
\text { group } \\
(\mathbf{n}=15)\end{array}$ & $\begin{array}{l}\text { Co Q10 } \\
\text { group } \\
(\mathbf{n}=19)\end{array}$ & $\begin{array}{l}\text { All cases } \\
(\mathbf{n}=34)\end{array}$ \\
\hline Maximum & 3750.00 & 150.00 & 150.00 \\
\hline Mean & 240.00 & 375.00 & 375.00 \\
\hline Std. deviation & 76.063 & 748.68 & 244.85 \\
\hline Median & 225.00 & 225.00 & 225.00 \\
\hline $\begin{array}{l}\text { Inter-quartile } \\
\text { range }\end{array}$ & $150.00-$ & $150.00-$ & $150.00-$ \\
\hline $\begin{array}{l}\text { KS test of } \\
\text { normality }\end{array}$ & $\begin{array}{l}\mathrm{D}=0.252 \\
\mathrm{p}=0.011^{*}\end{array}$ & $\begin{array}{l}\mathrm{D}=0.226 \\
\mathrm{p}=0.012^{*}\end{array}$ & $\begin{array}{l}\mathrm{D}=0.241 \\
\mathrm{p}=0.000^{*}\end{array}$ \\
\hline $\begin{array}{l}\text { Mann- } \\
\text { Whitney U }\end{array}$ & $\mathrm{Z}=0.310$ & & \\
Test & $\mathrm{p}=0.784 \mathrm{NS}$ & & \\
\hline
\end{tabular}

KS=Kolmogorov-Smirnov; *=statistically significant $(\mathrm{p}<0.05)$; NS: statistically not significant $(p>0.05)$

Doses of gonadotrophins used ranged from 150 IU TO 375 IU which did not show any statistically significant difference between the two groups (Table 3; $\mathrm{p}=0.784$ ). 
Duration of stimulation ranged from 12 to 15 days which was also statistically not significant between the two groups (Table 4; $\mathrm{p}=0.302$ ).

Table 4: Days of stimulation (days).

\begin{tabular}{|llll|}
\hline Minimum & $\begin{array}{l}\text { Placebo } \\
\text { group } \\
(\mathbf{n}=15)\end{array}$ & $\begin{array}{l}\text { Co Q10 } \\
\text { group } \\
(\mathbf{n}=19)\end{array}$ & $\begin{array}{l}\text { All cases } \\
(\mathbf{n}=34)\end{array}$ \\
\hline Maximum & 12.00 & 11.00 & 11.00 \\
\hline Mean & 15.00 & 15.00 & 15.00 \\
\hline Std. deviation & 1.000 & 12.63 & 12.79 \\
\hline Median & 13.00 & 1.012 & 1.008 \\
\hline $\begin{array}{l}\text { Inter-quartile } \\
\text { range }\end{array}$ & $12.00-$ & 12.00 & 12.50 \\
\hline $\begin{array}{l}\text { KS test of } \\
\text { normality }\end{array}$ & $\begin{array}{l}\mathrm{D}=0.241 \\
\mathrm{p}=0.019^{*}\end{array}$ & $\begin{array}{l}\mathrm{D}=0.313 \\
\mathrm{p}=0.000^{*}\end{array}$ & $\begin{array}{l}\mathrm{D}=0.284 \\
\mathrm{p}=0.000^{*}\end{array}$ \\
\hline $\begin{array}{l}\text { Mann-Whitney } \\
\text { U Test }\end{array}$ & $\begin{array}{l}\mathrm{Z}=1.113 \\
\mathrm{p}=0.302 \mathrm{NS}\end{array}$ & & \\
\hline
\end{tabular}

$\mathrm{KS}=$ Kolmogorov-Smirnov; $*=$ statistically significant $(\mathrm{p}<0.05)$ NS: statistically not significant $(\mathrm{p}>0.05)$

Serum estradiol level (E2) measured prior to HCG trigger ranged from 939 to $1790 \mathrm{pmol} / \mathrm{l}$ which was statistically not significant between the two groups (Table 5; $\mathrm{p}=0.554 \mathrm{NS})$.

Table 5: E2 level (pmol/l).

\begin{tabular}{|c|c|c|c|}
\hline & $\begin{array}{l}\text { Placebo } \\
\text { group } \\
(n=15)\end{array}$ & $\begin{array}{l}\text { Co Q10 } \\
\text { group } \\
(n=19)\end{array}$ & $\begin{array}{l}\text { All cases } \\
(n=34)\end{array}$ \\
\hline Minimum & 990.00 & 939.00 & 939.00 \\
\hline Maximum & 1790.00 & 1789.00 & 1790.00 \\
\hline Mean & 1339.33 & 1330.10 & 1334.17 \\
\hline Std. Deviation & 199.132 & 175.364 & 183.353 \\
\hline Median & 1290.00 & 1290.00 & 1290.00 \\
\hline $\begin{array}{l}\text { Inter-quartile } \\
\text { range }\end{array}$ & $\begin{array}{l}1211.00- \\
1480.00\end{array}$ & $\begin{array}{l}1230.00- \\
1478.00\end{array}$ & $\begin{array}{l}1225.25- \\
1478.50\end{array}$ \\
\hline $\begin{array}{l}\text { KS test of } \\
\text { normality }\end{array}$ & $\begin{array}{l}D=0.131 \\
p=0.200 \mathrm{NS}\end{array}$ & $\begin{array}{l}\mathrm{D}=0.128 \\
\mathrm{p}=0.200 \\
\mathrm{NS}\end{array}$ & $\begin{array}{l}D=0.125 \\
p=0.200 \\
\text { NS }\end{array}$ \\
\hline $\begin{array}{l}\text { Levene's Test } \\
\text { for Equality of } \\
\text { Variances }\end{array}$ & $\begin{array}{l}F=0.357 \\
p=0.554 \mathrm{NS}\end{array}$ & & \\
\hline $\begin{array}{l}\text { Independent } \\
\text { Samples t Test }\end{array}$ & $\begin{array}{l}\mathrm{t}_{\mathrm{df}=32)}=0.144 \\
\mathrm{p}=0.887 \mathrm{NS}\end{array}$ & & \\
\hline
\end{tabular}

$\mathrm{KS}=$ Kolmogorov-Smirnov; $*=$ statistically significant $(\mathrm{p}<0.05)$; NS: statistically not significant $(\mathrm{p}>0.05)$

Table 6: Pregnancy.

\begin{tabular}{|l|lll|}
\hline & $\begin{array}{l}\text { Group } \\
\text { Placebo } \\
(\mathbf{n = 1 5})\end{array}$ & $\begin{array}{l}\text { CoQ10 } \\
(\mathbf{n}=19)\end{array}$ & $\begin{array}{l}\text { All cases } \\
(\mathbf{n}=34)\end{array}$ \\
\hline Pregnancy & $4(26.67 \%)$ & $5(26.32 \%)$ & $9(26.47 \%)$ \\
\hline
\end{tabular}

The primary outcome (pregnancy) was achieved in only five cases in group A compared to four cases in group B which was statistically not significant (Table 6; p FE) $=1.000)$.

\section{DISCUSSION}

Interest in coenzyme Q10 as a supplement to improve fertility was sparked when a report from Canada said fertility in mice was improved when the mice were given Co Q10. The mice that were given coenzyme Q 10 before they were given ovarian stimulation made more follicles and better eggs compared to mice that were not given Co Q10. According to the researchers, the Co Q10 seemed to cause the older mice to produce eggs that functioned more like eggs from younger mice.

This study suggests the possibility of a fertility benefit for women with low ovarian reserve. This study failed to find a benefit from using co- enzyme Q10 prior to ovulation stimulation. The study results matched with the results of a controlled randomised trial designed by Bentov et al. evaluating the effect of CoQ10 on post-meiotic oocyte aneuploidy rate in women undergoing IVF, in Sinai Hospital, Toronto, Canada, it was a double-blind placebo study that included IVF-ICSI patients 35-43 years of age. ${ }^{15}$ The patients were treated with either $600 \mathrm{mg}$ of CoQ10 or an equivalent number of placebo caps. Researchers compared the post-meiotic aneuploidy rate using polar body biopsy (PBBX) and comparative genomic hybridization ( $\mathrm{CGH})$. According to the power calculation, 27 patients were needed for each arm. But owing to safety concerns regarding the effects of polar body biopsy on embryo quality and implantation, the study was terminated before reaching the target number of participants.

A total of 39 patients were evaluated and randomized (17 CoQ10, 22 placebo), 27 were given the study medication (12 CoQ10, 15 placebo), and 24 completed an IVF-ICSI cycle including PBBX and embryo transfer (10 CoQ10, 14 placebo). Average age, base line follicle stimulating hormone (FSH), peak estradiol and progesterone serum level, as well as the total number of human menopausal gonadotropin (hMG) units did not differ between the groups. The rate of aneuploidy was $46.5 \%$ in the CoQ10 group compared to $62.8 \%$ in the control. Clinical pregnancy rate was $33 \%$ for the CoQ10 group and $26.7 \%$ for the control group. They concluded that there were no significant differences in outcome between the CoQ10 and placebo groups. However, the final study was underpowered to detect a difference in the rate of aneuploidy.

On the other hand, a prospective controlled randomised trial by El Refaeey et al. investigating the combination of oral CoQ10 and clomiphene citrate to improve ovulation induction response in women with clomiphene-resistant polycystic ovary syndrome proved that this combination is an effective and safe option for improving ovulation and clinical pregnancy rates. ${ }^{16}$ 


\section{CONCLUSION}

In light of the above-mentioned studies and our study results, we concluded that CoQ10 supplementation may protect ovarian reserve by improving mitochondrial function, counteracting both mitochondrial ovarian ageing and physiological programmed ovarian ageing although the certain effect of OS in female infertility is not clearly known, but it has no significant effect on response to ovulation stimulation neither does it improve pregnancy rates.

\section{Recommendations}

Further experimental studies need to be designed to define the optimum dosage and duration for CoQ10 supplementation to enhance its protective effects. Furthermore, future studies are needed to understand the effect of CoQ10 on ovaries and human reproduction.

\section{ACKNOWLEDGMENTS}

Authors would like to thank Professor Dr. El Sayed Amr for his assistance in statistics.

Funding: No funding sources Conflict of interest: None declared

Ethical approval: The study was approved by the Institutional Ethics Committee

\section{REFERENCES}

1. Titus S, Li F, Stobezki R, Akula K, Unsal E, Jeong K et al. Impairment of BRCA1-related DNA doublestrand break repair leads to ovarian aging in mice and humans. Sci Transl Med. 2013;5(172):172.

2. Dumollard R, Ward Z, Carroll J, Duchen MR. Regulation of redox metabolism in the mouse oocyte and embryo. Development. 2007;134:455-65.

3. Harman D. Aging: a theory based on free radical and radiation chemistry. J Gerontol. 1956;11(3):298-30.

4. Meldrum DR. Aging gonads, glands, and gametes: immutable or partially reversible changes? Fertil Steril. 2013;99(1):1-4.

5. Li Q, Geng X, Zheng W, Tang J, Xu B, Shi Q. Current understanding of ovarian aging. Sci China Life Sci. 2012;55(8):659-69.
6. Bentov Y, Casper RF. The aging oocyte-can mitochondrial function be improved? Fertil Steril. 2013;99(1):18-22.

7. Santos-Ocana C, Do TQ, Padilla S, Navas P, Clarke CF. Uptake of exogenous coenzyme Q and transport to mitochondria is required for bc1 complex stability in yeast coq mutants. $J$ Biol Chem. 2002;277(13):10973-81.

8. Villalba JM, Navas P. Plasma membrane redox system in the control of stress-induced apoptosis. Antioxid Redox Signal. 2000;2000(2):213-30.

9. Pignatti C, Cocchi M, Weiss H. Coenzyme Q10 levels in rat heart of different age. Biochem Exp Biol. 1980;16(1):39-42.

10. IBM Corp. Released 2012. IBM SPSS Statistics for Windows, Version 21.0. Armonk, NY: IBM Corp.

11. Field A, ed. Discovering Statistics Using SPSS. 2nd ed. London, California, New Delhi:SAGE Publications Ltd;2006.

12. Welch BL. The generalization of Students' problem when several different population variances are involved. Biometrika. 1947;34(1-2):28-35.

13. Ruxton GD. The unequal variance t-test is an underused alternative to Student's t-test and the Mann-Whitney U test. Behav Ecol. 2006;17:688-90.

14. Mann HB, Whitney DR. On a Test of Whether one of two random variables is stochastically larger than the other. Annals Mathemat Statist. 1947;18(1):5060.

15. Bentov Y, Hannam T, Jurisicova A, Esfandiari N, Casper RF. Coenzyme Q10 supplementation and oocyte Aneuploidy in women undergoing IVF-ICSI treatment. Clin Med Insights Reprod Health. 2014;8:31-6.

16. Refaeey EA, Selem A, Badawy A. Combined coenzyme Q10 and clomiphene citrate for ovulation induction in clomiphene-citrate-resistant polycystic ovary syndrome. Reprod Biomed Online. 2014;29(1):119-24.

Cite this article as: El Fattah EAA. Can C0- enzyme Q10 improve the chances of conception after the age of 35?. Int J Reprod Contracept Obstet Gynecol 2017;6:2729-33. 